\title{
The Effectiveness of Using Brainstorming Strategy on the Development of Creative Thinking Abilities and Speed of Learning some Skills Kinetic Padres Physical Education
}

\author{
Dr. Mohamed Abdelkader Elsharkawy ${ }^{(*)}$
}

Hassan Mohamed (2014) adds that brainstorming is one of the essential techniques and strategies of motivating thinking and creation as collective thinking or individual way in solving a lot of different scientific and life problems .(3:58)

The modern education faces problems and challenges imposed by this era nature and it is trying to get them over. It is important to support learning process by perfect teaching strategy to reach the goal of learning process. This burden falls on the teacher so he has to develop students thinking inside the curriculum through following teaching strategy which shows the curriculum within it so as to develop the creation and thinking.(8:91)

\section{Research Aim:}

The research aims at knowing brainstorming strategy usage effect on the creative thinking and learning some motor skills in athletic education lesson to the second session students of the basic education"

\section{Research assumptions:}

1- There are assumptions statistically clear between the dimensional and premier measurements of the empirical group in the creative thinking and knowing some motor skills in athletic education for the dimensional.

2- There are assumptions statistically clear between the dimensional and premier measurements of the controlling group in the creative thinking and knowing some motor skills in athletic education for the dimensional measurement .

3- There are assumptions statistically clear between the two dimensions measurements of the empirical and controlling groups in the creative learning and knowing some motor skills in athletic education for the dimensional measurement of the empirical group

\section{Research approach:}

\footnotetext{
${ }^{(*)}$ Lecture In Curricula \& Teaching Methods In Ph.Ed.Dept At Faculty Of Physical Education Damietta University
} 
The researcher uses the empirical approach where it is the suitable approach of research nature. The researcher used one of the empirical designs which are the empirical design for two groups: one of them is empirical and the other is controlling the dimensional and premiere measurement of the two groups.

\section{Research society and sample:}

Research society represents first prep stage students in the Prep school of the Future of 2014/2015 in New Damietta Department of Education, who are (75) student and it includes (50) student . They are chosen among the first prep stage students and separated randomly into two equal groups: one is empirical consisting of (20) student, get learning using brainstorming strategy and the other is controlling consisting of (20) student, get learning using verbal explanation and model assessment. (10) Students are chosen for exploratory studies.

\section{Research sample compliance and harmony: Appendix (1)}

The harmony and compliance are done on the basic research sample to the empirical and controlling groups, consisting of (50) student of the first prep stage students from 14/10/2014 to 21/10/2014 of the changes that affect results accuracy and the suggested educational program process.

\section{The used tests}

\section{1-The test of the innovative thinking:}

The researcher used the innovative thinking test on the children of (9-12) years old, prepared by "Sayed khair Allah" 2006.

\section{2- The tests of the physical abilities:}

- The researcher used the following tests.

- Vertical jump test of steadiness.

- Pushing medical ball to the maximum distance.

- Running to 45 Meter distance.

- Running over rectangle $\left(10^{*} 16\right)$ feet.

- Bending the trunk forward from the standing.

\section{3-Motor skills tests:}

- Control the ball test.

- Dribbling speed Test.

- Scrolling speed. test

- Test of accuracy shooting from the free-throw.

- Test of peaceful shooting.

4 -Non-verbal intelligence test. Prepared by Ateyat Mohamed-The involved steps to apply brainstorming sessions:

Brainstorming session passes through number of stages that need accuracy in its application as required to ensure its success. These stages 
include as identified by" Akram ,Maamon 2008", Mohamed Abdraboh" 2012," Zeinab Mohamed" 2013 ," Hassan Mohamed Hassan 2014"asfollows.

\section{1-Issuse disscussion and identification (the subject ) :}

We may find that some of the participants are fully aware of the subject details where some others have simple idea about it and in this case, the leader has to give the participants the minimum limit of information about the subject because giving a lot of details may happen largely of their thinking board and being limited to restricted narrow fields.

\section{2 - Subject reformulation :}

Participants are asked to be out of the subject context as it is known and to identify its different dimensions and sides again. There may be another sides of the subject.

\section{3-preparing creativeness and brainstorming:}

The participants in brainstorming session need to be prepared tl creativeness atmosphere. It takes about 5 minutes when participants are trained to answer the questions by deceive leader.

\section{4- Brainstorming:}

The device leader writes the questions that are chosen through reformulation $\mathrm{g}$ the subject they get in the second stage. The participants are asked to present their ideas freely to be written down by notes writer on the specific board in conspicuous place with numbering the ideas according to its order. The leader can after that invite the participants to mediate or think of the presented ideas and generate the more of them .

\section{5- identifying the strangest idea:}

The leader can invite the participants to choose the strangest presented idea and the more far away from the mentioned ideas when there are no ideas. They are asked to transfer these ideas to practical useful 1 ones. At the end, the leader should thank the device operator and the participants for their contribution .

\section{6- assessment session :}

The aim of this session is to assess the ideas and identify what is needed, and sometimes the ideas are existed but not apparent to be disabused .The scientific factors of motor and physical skills of creativeness are under discussion

\section{Pre measure}

The pre measurements were conducted on the essential sample of research $i$ the 26/10/2014 to 27/10/2014. 


\section{Main experiment}

The main experiment was conducted on the main sample of research in the 28/10/2014 to 23/12/2014.

measure

\section{Post measurement}

The post measurements were conducted on the essential sample of research in the 24/12/2014 to $25 / 12 / 2014$.

\section{Results:}

Table (1)

Significance differences between the averages of the pre and post scales for the experimental on the innovative thinking and the motor skills in the Basketball under consideration.

$\mathbf{N}=\mathbf{2 0}$

\begin{tabular}{|c|c|c|c|c|c|c|c|c|}
\hline & \multirow{2}{*}{ Test } & \multirow{2}{*}{$\begin{array}{c}\text { Measure } \\
\text { ment } \\
\text { unit }\end{array}$} & \multicolumn{2}{|c|}{ pre tests } & \multicolumn{2}{|c|}{ post tests } & \multirow{2}{*}{$\begin{array}{c}\text { The } \\
\text { Difference }\end{array}$} & \multirow{2}{*}{$\begin{array}{c}\text { Value } \\
\text { (T) }\end{array}$} \\
\hline & & & $\overline{\mathbf{x}}$ & $\sigma$ & $\overline{\mathbf{x}}$ & $\sigma$ & & \\
\hline 1 & $\begin{array}{c}\text { Total } \\
\text { creativeness }\end{array}$ & Degree & 15.300 & 2.494 & 21.700 & 2.250 & 6.400 & $* 12.95$ \\
\hline 2 & Fluency & Degree & 7.850 & 1.814 & 11.650 & 2.539 & 3.800 & $* 14.20$ \\
\hline 3 & Flexibility & Degree & 4.850 & 1.182 & 8.500 & 1.000 & 3.650 & $* 10.43$ \\
\hline 4 & Originality & Degree & 2.600 & 0.753 & 1.550 & 0.759 & 1.050 & $* 4.09$ \\
\hline 5 & Ball control & Degree & 11.300 & 0.923 & 15.900 & 0.911 & $4.600-$ & $* 16.16$ \\
\hline 6 & $\begin{array}{c}\text { Dialogue } \\
\text { fastness }\end{array}$ & Second & 14.400 & 0.680 & 11.050 & 0.759 & 3.350 & $* 13.75$ \\
\hline 7 & $\begin{array}{l}\text { Passing } \\
\text { fastness }\end{array}$ & Second & 12.250 & 0.850 & 9.850 & 0.670 & 2.400 & $* 9.39$ \\
\hline 8 & Free throw & Degree & 4.225 & 0.316 & 6.850 & 0.745 & 2.625 - & $* 13.35$ \\
\hline 9 & $\begin{array}{c}\begin{array}{c}\text { Peaceful } \\
\text { aim }\end{array} \\
\end{array}$ & Degree & 0.648 & 0.077 & 1.900 & 0.718 & 1.251 & $* 8.28$ \\
\hline
\end{tabular}

$T$ value at degree 18 and certain level $0,05=1,75$

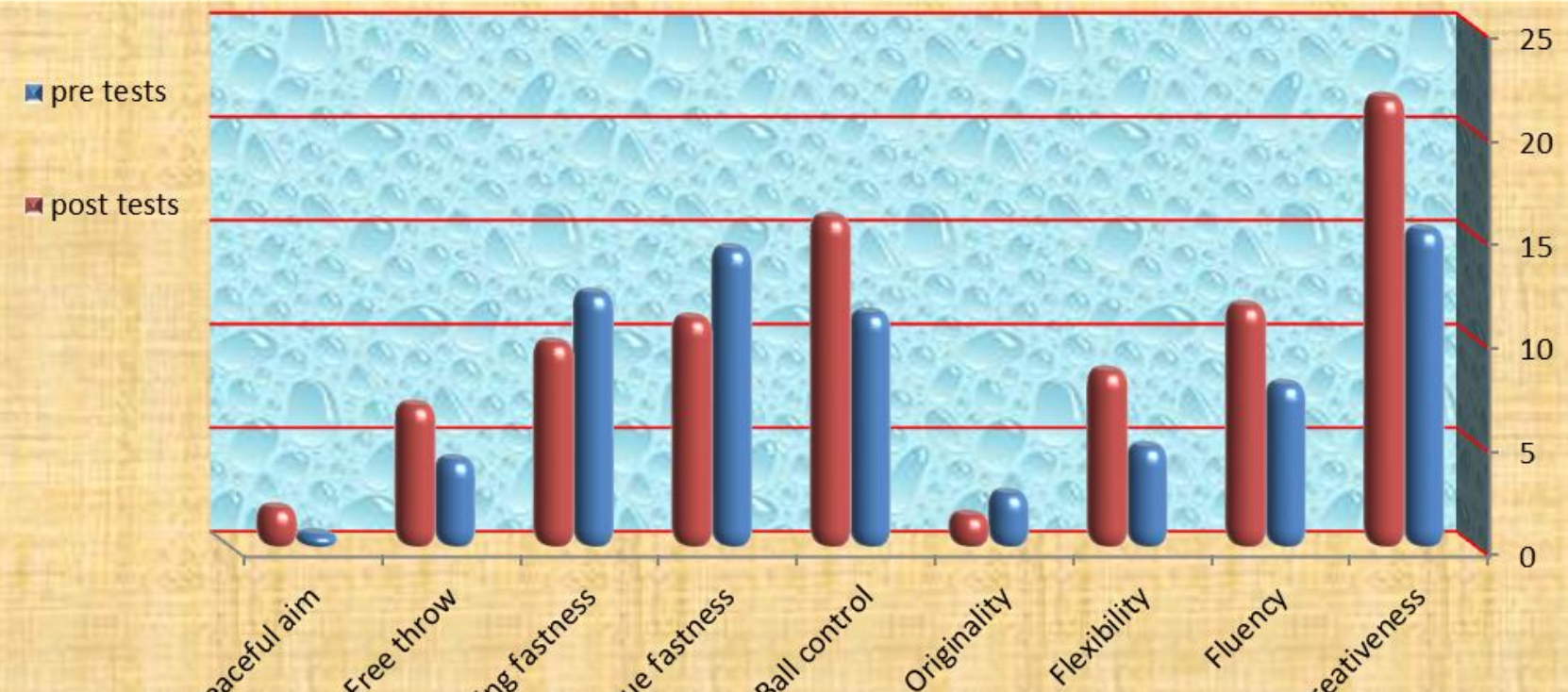




\section{Figure (1)}

Table (1) and figure(1) shows that identifies that there are identifying differences between the dimensional and premiere measurements for the empirical group in all motor skills and creative thinking measurement for dimensional measurement .

Showing up table results that there are differences between the dimensional and premiere measurements for the empirical group in creativeness exercise (dimensions and total degree) are under the discussion .

$\mathrm{T}$ value is limited and it is bigger at certain level 0.05 which shows that there are differences for dimensional measurement. Table(1) also shows that there are identifying differences between the two measurements in motor skills exercises under discussion where $\mathrm{T}$ value is limited and it is bigger than $\mathrm{T}$ in table at certain level 0.05 which show that there are differences for the dimensional and premiere measurement. The researcher aims the identifying progress in increasing creative exercises results and its dimensions at using brainstorming strategy in the main part (learning some motor skills in basketball) from athletic education lesson which undergo to basic rules and principles in application which lead to increasing motor performance level indirectly and lead to positive result on students (under discussion). This is clear through intelligence test improvement rates and total creativeness dimensions .

Brainstorming strategy usage in the educational program undergoes to four stages in the basic part of athletic education lesson which are (preparation, activation, ideas generating and assessment), the skill partition is done through it in motor mission shape by students . This can help to discover the cooperative and personal application as well as solving problems to be available in front of students during learning .

"Akram Maamoun(2008)" refers that learning based on discovering is based on the active level of learner and his abilities to precognition and intuitive thinking in educational material structure (31:39). 
this corresponds with what Hassan Mohamed Hassan 2014 that modern teaching models allow the learners to think of large number of solutions for one problem (116:3).

The researcher identifies the importance of brainstorming strategy that it care for the individual differences among students at application and it suits all ages and levels. It is one of strategies that enhance creative thinking. It is considered as state of mental liberation of person to get the creative solution of the presented problem. It also develops person ability to solve problems in creative way through making it available for all to generate large number of ideas in spontaneous, quick and free way , it can also help to solve one problem and then choosing the best solution

This corresponds "with miller 2004", "Nonis 2001" , "Doha Ehataby 2002", "Mohamed el Komy" 2003 and "Mohamed abd" rahou studies using teaching modern strategies develop the mental abilities as creativeness' for teacher .

We found that students answers of the questions raised during the performance or applications depend on oneself . Students sharing in dialogue and discussion with teacher help to understand and acknowledge information and knowledge related to motor skills (under discussion) and difficult to understand and difficult to forget.

This corresponds with studies results of" Akram Maamoun2008, Mohamed abd rabu 2008". This achieves assumption one of the study which stipulates that "there are clear differences between the dimensional and premiere measurements of empirical group in creative thinking and learning some motor skills in athletic education lesson for dimensional measurement".

Table(2)

Significance differences between the averages of the pre and post scales for the experimental on the innovative thinking and the motor skills in the Basketball under consideration.

$\mathbf{N}=\mathbf{2 0}$

\begin{tabular}{l|c|c|c|c|c|c}
\hline \hline & Test & Measure & pre tests & post tests & The & Value \\
\hline
\end{tabular}




\begin{tabular}{|c|c|c|c|c|c|c|c|c|}
\hline & & $\begin{array}{c}\text { ment } \\
\text { unit }\end{array}$ & $\overline{\mathbf{x}}$ & $\sigma$ & $\overline{\mathbf{x}}$ & $\sigma$ & Difference & (T) \\
\hline 1 & $\begin{array}{c}\text { Total } \\
\text { creativeness }\end{array}$ & Degree & 15.850 & 2.758 & 17.800 & 2.015 & 1.9500 & $* 4.174$ \\
\hline 2 & Fluency & Degree & 8.700 & 1.559 & 9.050 & 1.099 & 0.350 & $* 2.333$ \\
\hline 3 & Flexibility & Degree & 5.50 & 1.356 & 5.500 & 1.235 & 0.450 & *2.932 \\
\hline 4 & Originality & Degree & 2.750 & 0.716 & 3.250 & 0.910 & 0.500 & $* 3.684$ \\
\hline 5 & Ball control & Degree & 11.400 & 1.142 & 12.750 & 0.638 & 1.350 & $* 4.133$ \\
\hline 6 & $\begin{array}{l}\text { Dialogue } \\
\text { fastness }\end{array}$ & Second & 14.500 & 0.760 & 12.500 & 0.606 & 2.00 & $* 10.420$ \\
\hline 7 & $\begin{array}{l}\text { Passing } \\
\text { fastness }\end{array}$ & Second & 12.000 & 1.123 & 11.550 & 0.510 & 0.450 & $* 1.690$ \\
\hline 8 & Free throw & Degree & 4.325 & 0.224 & 4.650 & 0.759 & 0.625 & $* 3.372$ \\
\hline 9 & $\begin{array}{c}\text { Peaceful } \\
\text { aim }\end{array}$ & Degree & 0.611 & 0.061 & 0.825 & 0.372 & 0.214 & $* 2.376$ \\
\hline
\end{tabular}

$T$ value in the table at 18 degree and certain level $0,05=1,75$

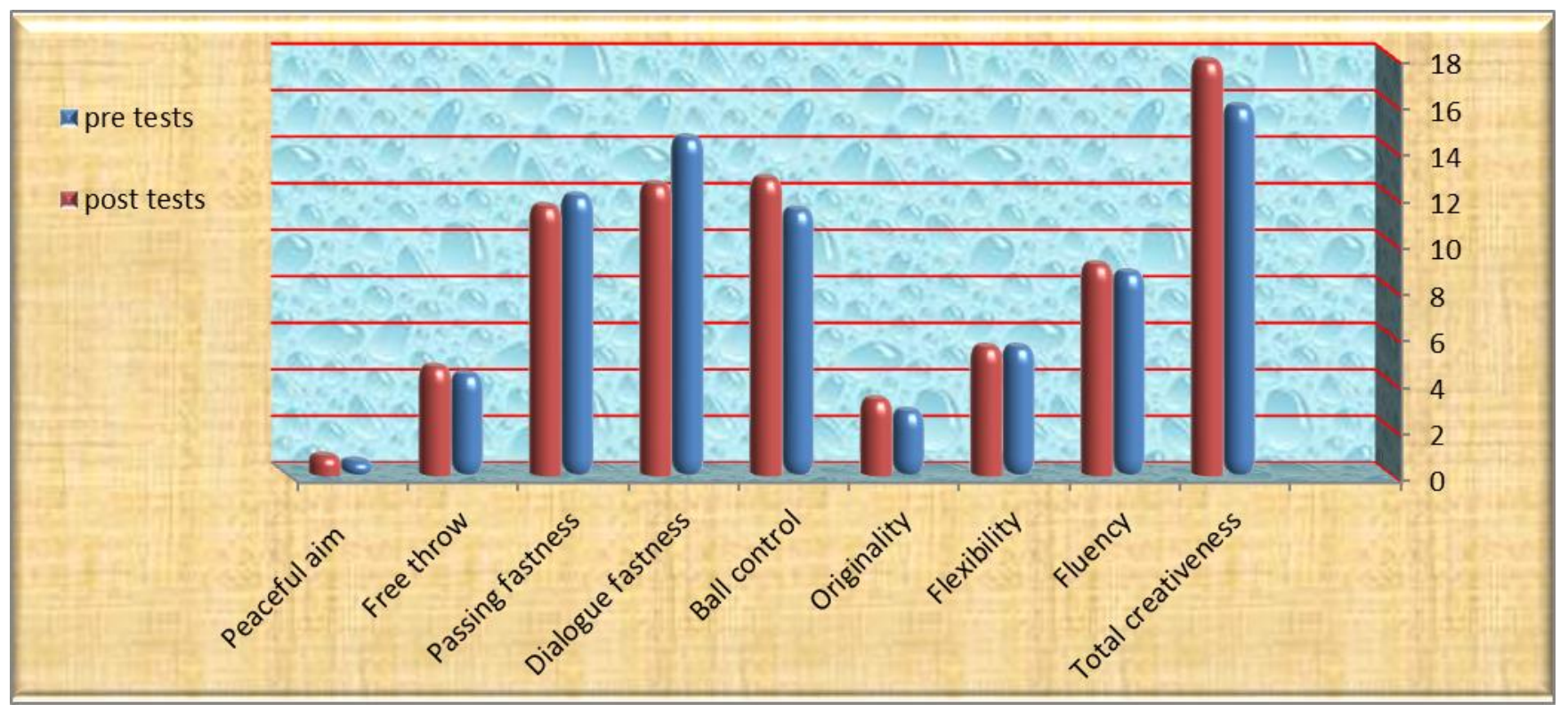

Figure (2)

Table (2) and figure(2) shows that there are clear differences between the dimensional and premiere measurement of the controlling group in all skillful exercises and creative thinking measurement for dimensional measurement .

Through showing table 6 we find that there are statistic differences between the dimensional and premiere for

the controlling group in creativeness exercise (dimensions and low degrees) under discussion where $t$ counted value is bigger than $t$ in the table at certain level 0,05 that shows that there are clear differences of controlling groups dimensions . 
Table (2) shows that there are clear differences between the dimensional and premiere measurements of controlling group in creativeness exercises under discussion where $t$ value counted is limited and it is bigger than its value in the $t$ in the table at certain level 0,05 which show that there are clear differences between the dimensional and premiere measurement for the controlling group.

The researcher knows the progress the controlling group achieved in motor skills exercise under discussion which used the traditional followed technique(explanation and model) hides in this way that cannot be ignored, where it depends on explanation and giving good model of the wanted skill to be learned. The improvement in the controlling group in controlling group performance goes back to the followed way in education through the different stages of education.

This corresponds with what Mahmoud Abu Alatta 2010 of learner performance of skills depend on teacher skills in teaching, good explanation and preparing model for all the skills to be learned under discussion(15:84)

Osman Mustafa (2003 )that teacher is the axis of education: he corrects students works and asses them. He also corrects the skillful performance whereas the student accepts the ideas without debate and sees that the teacher is the responsible for his success $(10: 180)$.

This can correspond with the study of" Fatma Mohamed 2003, Fatma ahmed2005, Randa ibrahim2009, Mohamed Abdraouh 2012 and Zeinab Mohamed 2013" .

This achieves the assumption two of the study which stipulates that " there are clear statistic differences between the dimensional and premiere measurements of the controlling group in the creative thinking and learning some of the motor skills in athletic education lesson for the. 
Table(3)

Significance differences between the averages of the two post scales for the control groups on the innovative thinking and the motor skills in the Basketball under consideration.

\begin{tabular}{|c|c|c|c|c|c|c|c|c|}
\hline & \multirow{2}{*}{ Test } & \multirow{2}{*}{$\begin{array}{c}\text { Measure } \\
\text { ment } \\
\text { unit }\end{array}$} & \multicolumn{2}{|c|}{$\begin{array}{c}\text { Experimental } \\
\text { Group } \\
\end{array}$} & \multicolumn{2}{|c|}{ Control Group } & \multirow{2}{*}{$\begin{array}{c}\text { The } \\
\text { Difference }\end{array}$} & \multirow{2}{*}{$\begin{array}{l}\text { Value } \\
(\mathbf{T})\end{array}$} \\
\hline & & & $\overline{\mathbf{x}}$ & $\sigma$ & $\overline{\mathbf{x}}$ & $\sigma$ & & \\
\hline 1 & $\begin{array}{c}\text { Total } \\
\text { creativeness }\end{array}$ & Degree & 21.700 & 2.250 & 17.800 & 2.015 & 3.900 & $* 5.773$ \\
\hline 2 & Fluency & Degree & 11.650 & 2.539 & 9.050 & 1.099 & 2.600 & $* 4.202$ \\
\hline 3 & Flexibility & Degree & 8.500 & 1.000 & 5.500 & 1.235 & 3.000 & 8.441 \\
\hline 4 & Originality & Degree & 1.550 & 0.759 & 3.250 & 0.910 & 1.700 & $* 6.413$ \\
\hline 5 & Ball control & Degree & 15.900 & 0.911 & 12.750 & 0.638 & 3.1500 & $* 12.653$ \\
\hline 6 & $\begin{array}{l}\text { Dialogue } \\
\text { fastness }\end{array}$ & Second & 11.050 & 0.759 & 12.500 & 0.606 & 1.4500 & $* 6.672$ \\
\hline 7 & $\begin{array}{l}\text { Passing } \\
\text { fastness }\end{array}$ & Second & 9.850 & 0.670 & 11.550 & 0.510 & 1.700 & *9.019 \\
\hline 8 & Free throw & Degree & 6.850 & 0.745 & 4.950 & 0.759 & 1.900 & *7.988 \\
\hline 9 & $\begin{array}{c}\text { Peaceful } \\
\text { aim }\end{array}$ & Degree & 1.900 & 0.718 & 0.825 & 0.372 & 1.075 & *5.942 \\
\hline
\end{tabular}

$T$ value at degree 38 and certain level $0,05=1.96$

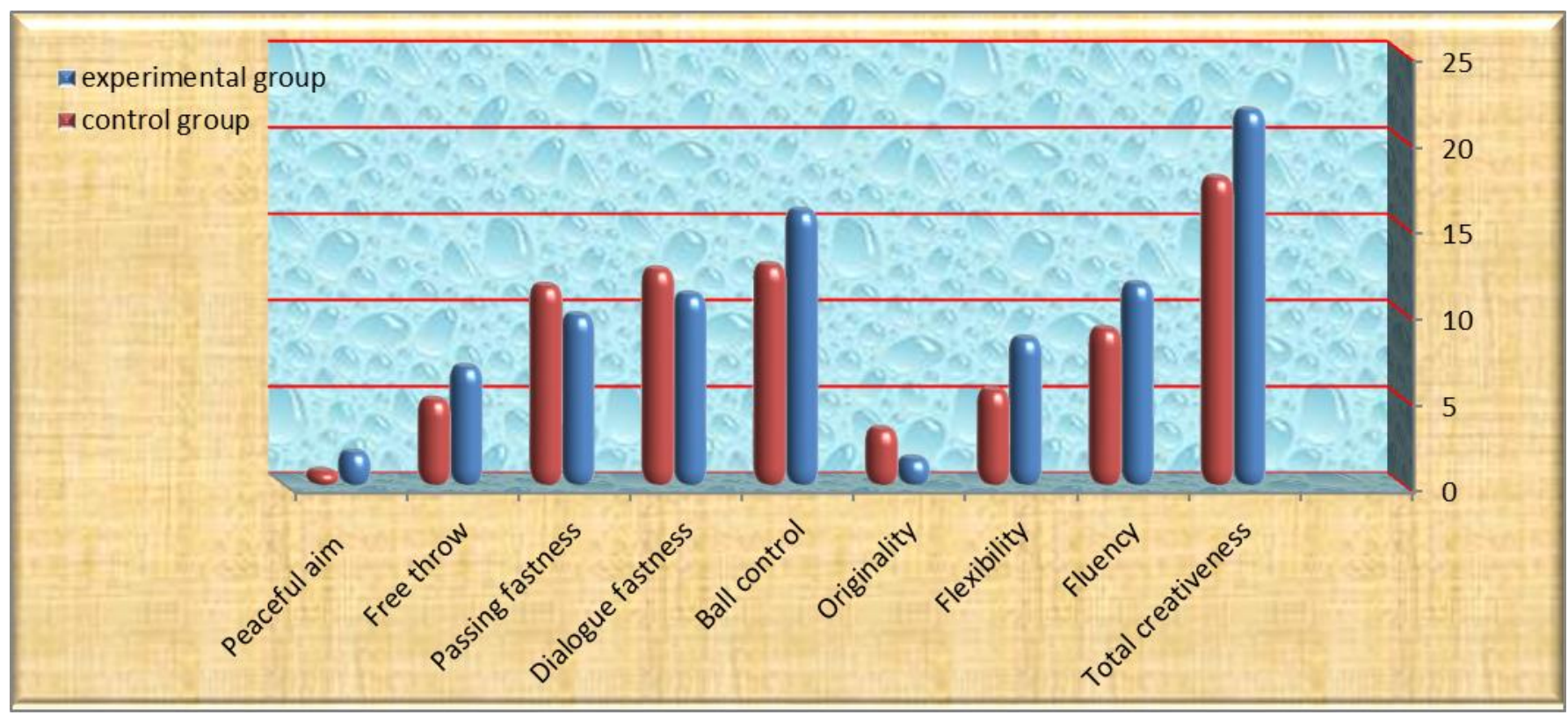

Figure (3)

Table (3) and figure (3) shows that 3 that there are clear differences between empirical and controlling groups in the dimensional measurement for all motor skills and creative thinking measurement under discussion for the empirical group . 
The researcher relates these differences for the empirical grouping the dimensional measurement of the controlling group that students don't accept the traditional way of teaching technique that give along period and students lose fast responsiveness . This makes students suffer border in addition to non-positive sharing and effectiveness inside the educational unit, so the researcher employs brainstorming strategy to develop creativeness. The strategy is used through the motor skills of basketball (under discussion) inside the

This complies with what" Mohamed Abd rabouh 2012" referred to that taking into account the former experiences of learners and make it point of new teaching that makes teaching successful (59).

This also complies with what "Rashad Mousa and Seham Khatab 2004" mentioned that creative development techniques are based on learning according to using the modern teaching strategy in learning and depend on dialogue means and discussion that develop creativeness (117)

He researcher declares that brainstorming strategy has taken into account level, abilities and the individual differences among learners to learn the motor skills under discussion that is characterizes by logical order in an organized and following way that helps to concentrate and understand every part easily .

In addition to this, brainstorming strategy helps to create a lot of mental abilities to students like criticism, analysis and comparisons between skill performance and what students see on the visual device in preparation stage, and this what is corresponded with "Hassan Mohamed 2013" that facing problems related to students helps to build meaning to what they learn and develop the confidence in their ability to solve problems (7:17).

This complies with the study of" karma maamoun2008" and"zeinab mohamed2013", and this achieves assumption three of the study that stipulates that " there are differences between the dimensions measurements of controlling and empirical in creative thinking and learning some motor skills in athletic education lesson for dimensional measurement of empirical group .

\section{Conclusions:}

1- Using the suggested brainstorming strategy leads to positive effect on motor skills level progress in basketball (under discussion), using this strategy in activation and preparation, and the speed of learning these skills .

2- The use of brainstorming strategy results in positive impact on level of the innovative thinking and the motor skills with the experimental sample of research, and the speed of learning these skills . 


\section{The Recommendations:}

1- Applying the suggested educational program through using brainstorming strategy .

2- Doing a lot of empirical researches using another modern ways related to education technology.

\section{References:}

1- Ahmed Amin Fawzi and Mohmed Abdul-Aziz salma 2002, :basketball for beginners, alfanyia for copying and publishing, Alexandria

2- Akram Maamoun 2008: the effect of using brainstorming technique on learning some of basketball skills , master thesis at athletic education faculty in al Haram ,for boys, Helwan university

3- Hassan Mohamed Hassan,2009 : the effect of using brainstorming and excluding strategies in developing the creative thinking in Islamic education for the eighth students stage in Jordan, athletic education faculty magazine of number 97 , benha university

4- Rashad mousa and Seham Khtab,2004 :creativeness, dar alfekr alaraby,cairo.

5- Randa Ibrahim fathy,2009 : the effect of using brain storming strategy on knowledge and its relation to the fastness of learning some of the motor skills in water ball, master thesis of athletic education faculty ,Zagazig u iversity .

6- Zeinab Ahmed Mahmoud,2013: the effectiveness of using brainstorming stratagey in athletic education lesson on creativeness to girls students of the first prep stage , master thesis, athletic education faculty, al Mansoura university .

7- Zaied al hwaydr,2002 : effective teaching skills, alktab al gamaaeyb. Alayeen, the arb united emirates

8- Doha al atabeyb: the effect $\mathrm{t}$ of using brainstorming strategy in developing the creative thinking and studying in science for the first middle stage students i. Alryaad, master thesis, girls faculty ,Alryad university .

9- Abdullah mater,2003 :learning strategy, alhashimia university, Jordan .

10- Osman Mostafa Osman,2003: comparing the learning structure model and the integration way on some motor skills and the ability of the creative thinking in athletic education lesson for the prep stage students, published research, athletic education faculty, alMinia .

11- Fatma Ahmed Hassan,2005 :the effect of educational program using the individual educational media technique through computer to learn some of basketball skills for student girls, teaching section in Tanta athletic education faculty, Alminia university, athletic education faculty . 
12- Fatma Mohamed Folifel,2003: educational program effect using hypermedia to learn some of basketball skills for the second session girls students of the basic education, Alminia university, athletic education faculty .

13- Mohamed Abd rabouh ,2012 : the effectiveness of using brainstorming technique for the students who face difficulties in motor skills in athletic education lesson in primary stage ,master thesis ,Al Mansoura university ,education faculty.

14- Mohamed al komy,2003 : the effect of using brainstorming strategy in teaching history on developing the creative thinking for the first secondary stage students in Oman sultanate, master thesis, education faculty, a sultan qabous university, Oman sultanate, 23 .

15- Mahmoud Mohamed Abu alatta,2010 : the effect of using remote learning on knowledge and motor level of basketball, unpublished master thesis, athletic education faculty , Banha university.

16- Millier $\mathbf{j} \mathbf{~ h ~} 2004$. The effectiveness of training of creative thin ring ability of third grade children DAL Vol 37,1225

17- Nonis ailleenet al, 2000: technology and teacher preparation creating student involvement a d creativity the university of tennese. 
Attachments

$-13-$ 


\section{Attachment (1)}

\section{Table (1)}

The mathematical average, standard diversion , coefficient flexure of research sample in changes of ( age, length, weight, intelligence rate, physical, skillful and creative tests )

$\mathrm{N}=50$

\begin{tabular}{|c|c|c|c|c|c|}
\hline Research changes & $\begin{array}{l}\text { Measurement } \\
\text { unit }\end{array}$ & $\overline{\mathbf{x}}$ & $\sigma$ & $\begin{array}{l}\text { Standard } \\
\text { diversion }\end{array}$ & $\begin{array}{l}\text { coefficient } \\
\text { flexure }\end{array}$ \\
\hline Age & Year & 11.54 & 0,54 & 12.00 & -0.65 \\
\hline Length & Centimeter & 146,10 & 2.47 & 147,00 & -1.32 \\
\hline Weight & KG & 44,52 & 1.36 & 44,00 & 0.29 \\
\hline Intelligence & Degree & 155,60 & 26.90 & 171,00 & 0.77- \\
\hline Total creativeness & Degree & 15,78 & 2.97 & 16.0 & $0.32-$ \\
\hline Fluency & Degree & 8.46 & 2.01 & 8.00 & 0.01- \\
\hline Flexibility & Degree & 4.72 & 1.31 & 5.00 & 0.15 \\
\hline Originality & Degree & 2.60 & 0.73 & 2.00 & 0.79 \\
\hline Legs muscle ability & Centimeter & 24.46 & 1.28 & 25.00 & $\overline{0.94-}$ \\
\hline Arms muscle ability & Centimeter & 250.60 & 8.67 & 250.00 & $.0 .71-$ \\
\hline Fitness & Second & 19.14 & 0.81 & 19.00 & $0.02-$ \\
\hline Fastness & Second & 7.46 & 0.79 & 7.00 & 0.27 \\
\hline Flexibility & Centimeter & 4.58 & 0.84 & 4.00 & 0.28 \\
\hline Ball control & Degree & 11.40 & 1.03 & 12.00 & 0.05 \\
\hline Dialogue fastness & Second & 14.42 & 0.67 & 14.00 & 0.51 \\
\hline Passing fastness & Second & 12.04 & 0.95 & 12.00 & 0.23- \\
\hline Free throw & Degree & 4.32 & 0.28 & 4.40 & 0.43- \\
\hline Peaceful aim & Degree & 0.60 & 0.07 & 0.57 & 1.40 \\
\hline
\end{tabular}

It is clear from table (4) that flexure coefficient of research sample in changes ( age -length -weight -intelligence as one of the mental abilities -physical tests - creativeness- motor skills ) are limited between (+-3) which identifies sample individuals harmony in these changes . 
Table (2)

Assumptions identification between the empirical and

$\mathbf{N}=\mathbf{4 0}$ controlling groups in changes are under discussion

\begin{tabular}{|c|c|c|c|c|c|c|c|}
\hline \multirow{2}{*}{$\begin{array}{c}\text { Research } \\
\text { changes }\end{array}$} & \multirow{2}{*}{$\begin{array}{l}\text { Measureme } \\
\text { nt unit }\end{array}$} & \multicolumn{2}{|c|}{$\begin{array}{c}\text { Empirical } \\
\text { Group }\end{array}$} & \multicolumn{2}{|c|}{ Controlling group } & \multirow{2}{*}{$\begin{array}{c}\text { The } \\
\text { difference } \\
\text { between } \\
\text { two } \\
\text { averages } \\
\end{array}$} & \multirow{2}{*}{$\begin{array}{l}\text { Value } \\
(\mathbf{T})\end{array}$} \\
\hline & & $\overline{\mathbf{x}}$ & $\sigma$ & $\overline{\mathbf{x}}$ & $\sigma$ & & \\
\hline Age & Year & 11,56 & 0,502 & 11,5500 & 0.6 & 0.050 & 0.28 \\
\hline Length & \begin{tabular}{|l|} 
Centimeter \\
\end{tabular} & 146,300 & 1.190 & 145.10 & 3.0 & 1.100 & 1.387 \\
\hline Weight & KG & 44,550 & 2.49 & 45.050 & 1.3 & 0.500- & 1.239 \\
\hline Intelligence & Degree & 116.90 & 1.81 & 117.70 & 2.0 & 0.800- & 1.448 \\
\hline Total creativeness & Degree & 15.30 & 2.49 & 8.70 & 2.7 & 550- & 0.661 \\
\hline Fluency & Degree & 8.85 & 1.81 & 5.05 & 1.559 & 850- & 1.589- \\
\hline Flexibility & Degree & 4.850 & 1.18 & 2.75 & 1.3 & 200- & 0.497- \\
\hline Originality & Degree & 2.60 & 0.753 & 24.30 & 0.7 & 150- & 0.645- \\
\hline Legs muscle ability & Centimeter & 24.2580 & 1.251 & 250 & 1.4 & 050- & 0.118 \\
\hline $\begin{array}{c}\text { Arms muscle } \\
\text { ability }\end{array}$ & Centimeter & 249.50 & 9.445 & 18.95 & 8.5 & 500- & 0.175 \\
\hline Fitness & Second & 19,400 & 0.820 & 18.95 & 75 & 450 & 1.800 \\
\hline Fastness & Second & 7.100 & 0.788 & 7.250 & 786 & 150- & 0.603 \\
\hline Flexibility & Centimeter & 4.150 & 0.760 & 4.300 & 801 & 150- & 0.642 \\
\hline Ball control & Degree & 11.300 & 923 & 11.500 & 1.142 & 1.00- & 0.304 \\
\hline Dialogue fastness & Second & 14.400 & 0.680 & 14.000 & 0.760 & 0.100- & 0.438 \\
\hline Passing fastness & Second & 12.250 & 0.850 & 12.00 & 1.123 & 0.250 & 0.793 \\
\hline Free throw & Degree & 4.225 & 0.613 & 4.235 & 0.224 & $0.1000-$ & 1.154 \\
\hline Peaceful aim & Degree & 0.648 & 0.077 & 0.611 & 0.061 & 0.037- & 1.697 \\
\hline
\end{tabular}

$\mathrm{T}$ value at certain level $0.05=2.684$

It is clear in table ( 2 ) tat there are no statistic difference at level 0.05 between the two groups ( empirical and controlling ) in of the research changes which refer to the two groups compliance . 


\section{Attachment (2)}

The scientific factors of motor and physical skills of creativeness are under discussion A-tests trust

: Difference trust of motor

and physical tests are counted and creative thinking as well ,through test application on two groups of students, special group consisting of 10 students, the normal group consisting of 10 students. The two groups are out of research sample and representing research sample

Table (3)

The mathematical average, standard diversion and $T$ value between the special and normal groups in the physical and motor exercises $\mathrm{N} 1=\mathrm{N} 2=10$

\begin{tabular}{|c|c|c|c|c|c|c|c|}
\hline \multirow{2}{*}{ Tests } & \multirow{2}{*}{$\begin{array}{l}\text { Measurem } \\
\text { ent unit }\end{array}$} & \multicolumn{2}{|c|}{$\begin{array}{c}\text { Empirical } \\
\text { Group }\end{array}$} & \multicolumn{2}{|c|}{ Controlling group } & \multirow{2}{*}{$\begin{array}{c}\text { The } \\
\text { difference }\end{array}$} & \multirow{2}{*}{$\begin{array}{c}\text { Value } \\
(\mathbf{T})\end{array}$} \\
\hline & & $\overline{\mathbf{x}}$ & $\sigma$ & $\overline{\mathbf{x}}$ & $\sigma$ & & \\
\hline Total creativeness & Degree & 21,200 & 1.715 & 14.500 & 1.813 & 6.700 & 7.015 \\
\hline Fluency & Degree & 12.00 & 2.00 & 7.50 & 1.581 & 4.500 & 1.470 \\
\hline Flexibility & Degree & 7.666 & 0.707 & 6.400 & 1.173 & 3,066 & 6.795 \\
\hline Originality & Degree & 1.666 & 0.707 & 117.70 & 0.699 & 0.0.733. & 2.226 \\
\hline Vertical jumping test & Degree & 25.200 & 0.788 & 2.400 & 1.2.057 & 8100 - & 7.045 \\
\hline $\begin{array}{c}\text { Medical ball kicking } \\
\text { test }\end{array}$ & Centimeter & 254,00 & 6.992 & 33.300 & 12.297 & 44,0000 & 11.653 \\
\hline $\begin{array}{c}\text { Running around } \\
\text { rectangle }\end{array}$ & Centimeter & 19.000 & 0.816 & 298.00 & 0.875 & $5,100-$ & 9.839 \\
\hline Originality & Second & 7.700 & 0.823 & 13.900 & 0.674 & 2.000 & 13,471 \\
\hline Running at 45 meter & Second & 4.800 & 0.918 & 5.700 & 0.632 & 5,800 & 5.6414 \\
\hline Ball control test & Degree & 11.600 & 9.1.074 & 7.400 & 12.200 & 20,080 & 15.280 \\
\hline Fast maneuvering test & second & 14.300 & 0.483 & 12.200 & 0.632 & 1.600 & 8,435 \\
\hline Fast passing test & Second & 11.700 & 0.674 & 10.100 & 0.567 & 20- & 5,737 \\
\hline Free throw test & Degree & 4.520 & 0.204 & 6.060 & 0.834 & 20.80 & 0.642 \\
\hline Peaceful aiming & Degree & 0.562 & 0.007 & 2.000 & 0.816 & 11,438 & 5.569 \\
\hline
\end{tabular}

$R$ value in table at certain level $0,05=0,5219$

Table 4 identifies that $R$ the counted value is bigger than its value at B-tests stability 
To count tests stability, the researcher used the re-test way through applying this test on sample consisting $\mathrm{g}$ of 10 students and representing of research sample and out of the original sample at interval 7 days between the two applications . relating coefficients are counted between the first and second application to find stability of these exercises . Table 4 identifies relating coefficient

Table (4)

The mathematical average, standard diversion and relating coefficient between the two applications: the first and the second of the physical exercises

\begin{tabular}{|c|c|c|c|c|c|c|}
\hline \multirow{2}{*}{ Tests } & \multirow{2}{*}{$\begin{array}{l}\text { Measureme } \\
\text { nt unit }\end{array}$} & \multicolumn{2}{|c|}{$\begin{array}{c}\text { First } \\
\text { Application }\end{array}$} & \multicolumn{2}{|c|}{ Second application } & \multirow{2}{*}{$\begin{array}{l}\text { Relating } \\
\text { coefficient }\end{array}$} \\
\hline & & $\overline{\mathbf{x}}$ & $\sigma$ & $\overline{\mathbf{x}}$ & $\sigma$ & \\
\hline Total creativeness & Degree & 14.50 & 2.273 & 12.300 & 1.766 & $0.678 *$ \\
\hline Fluenc & Degree & 7.500 & 1.581 & 6.600 & 1.712 & $0.944 *$ \\
\hline Flexibility & Degree & 4.600 & 1.173 & 3.900 & 0.994 & $0.935^{*}$ \\
\hline Originality & Degree & 2.400 & 0.699 & 2.00 & 0.816 & $0.645^{*}$ \\
\hline $\begin{array}{c}\text { Vertical jumping } \\
\text { test }\end{array}$ & Centimeter & 25.200 & 0.788 & 25.300 & 0.843 & $0.869 *$ \\
\hline $\begin{array}{c}\text { Medical ball kicking } \\
\text { test }\end{array}$ & Centimeter & 254,00 & 6.992 & 254.500 & 6.851 & $0.825^{*}$ \\
\hline $\begin{array}{c}\text { Running around } \\
\text { rectangle }\end{array}$ & Centimeter & 19.000 & 0.816 & 19.300 & 0.823 & $0.826^{*}$ \\
\hline Originality & Second & 7.700 & 0.823 & 7.900 & 0.737 & $0.860 *$ \\
\hline Running at 45 meter & Second & 4.800 & 0.918 & 5.000 & 0.816 & $0.889 *$ \\
\hline $\begin{array}{c}\text { Drape the trunk of } \\
\text { the stand }\end{array}$ & Centimeter & 4.800 & 0.918 & 5.000 & 0.816 & $0.889 *$ \\
\hline Ball control test & Degree & 11.600 & 1.074 & 11.800 & 0.918 & $0.810 *$ \\
\hline $\begin{array}{c}\text { Fast maneuvering } \\
\text { test }\end{array}$ & Second & 14.300 & 0.483 & 14.400 & 0.516 & $0.802^{*}$ \\
\hline Fast passing test & Second & 11.700 & 0.674 & 11.900 & 0.737 & $0.825^{*}$ \\
\hline Free throw test & Degree & 4.520 & 0.204 & 4.560 & 0.222 & $0.901 *$ \\
\hline Peaceful aiming & Degree & 0.562 & 0.007 & 0.564 & 0.009 & $0.904 *$ \\
\hline
\end{tabular}

$R$ value in table at certain level $0,05=0,5219$

Table 4 identifies that $R$ the counted value is bigger than its value at 